This is the accepted manuscript of the following article:

López, A., García, M., Esteban-García, A. L., Cuartas, M., Molleda, A., \& Lobo, A. (2017). Emissions from mechanically biologically treated waste landfills at field scale. International Journal of Environmental Science and Technology, 1-16.

The manuscript has been published in final form at:

https://doi.org/10.1007/s13762-017-1497-6 


\title{
Emissions from mechanically-biologically treated waste landfills at field scale
}

\begin{abstract}
Modern waste management tends towards greater sustainability in landfilling, with the implementation of strategies such as the pretreatment of solid waste. This work assesses the behaviour of rejects from a refining stage of mechanically-biologically treated municipal solid waste at the landfill. The main results of 18 months' monitoring of an experimental pilot cell with waste from a full-scale plant are presented. This first stages are expected to be the most problematic period for this type of waste. The evolution of the temperature and the composition of leachate and gas at various points within the cell are included. During the first weeks, pollutant concentrations in the leachate exceeded the reference ranges in the literature, coinciding with a rapid onset of methanogenic conditions. However, there was a quick wash, reducing concentrations to below one third of the initial values before the first year. $\mathrm{pH}$ values influenced concentrations of some pollutants such as copper. These results indicate that, right from the beginning of disposal, such facilities should be prepared to treat a high pollution load in the leachate and install the gas emissions control elements due to the rapid onset of methanogenesis.
\end{abstract}

Keywords: MBT waste, leachate, landfill gas, pilot cell 


\section{INTRODUCTION}

In just a few years the controlled landfill (or sanitary landfill) has gone from being considered as the best technical solution to the search for options for zero discharge (European Council 2008), by recycling and recovery of many discarded materials. Moreover, in order to minimize landfill emissions, final rejects often undergo a stabilization process before being dumped (European Council 2009). The treatment of waste prior to sending it to a landfill has become a popular method of satisfying this requirement in order to reduce its biodegradability (Donovan et al. 2010). As a result of this development, the characteristics of the materials dumped in many countries are today very different from those received in traditional landfills. This leads to the need to adapt or generate criteria for the design, operation, closure and even post-closure monitoring and maintenance of these facilities.

Specifically, in Europe, a large portion of the waste reaching landfills has previously undergone a mechanical-biological treatment (MBT). MBT plants include separation stages for recyclable materials that have not been previously retrieved, and some type of aerobic or anaerobic biological treatment, called biostabilization, which reduces the biodegradability of the organic fraction to decrease liquid and gaseous emissions once dumped in the landfill.

In the European framework there are different situations. While in countries like Germany and Austria the pretreated waste is landfilled directly, in others where the selective collection of the organic fraction has not yet been extended, such as Spain, the stabilized organic matter generated in many of the MBT facilities is used for soil conditioning in different applications. Thus, these facilities include a refining treatment after biostabilization, which allows the impurities or "rejects" to be separated out from the biostabilized fraction. Even though the pretreatment practices are different, the behaviour of the landfilled waste might have similarities, because in both cases, the content of organic matter has been drastically reduced and the residual fraction stabilized.

Many of the studies focused on the performance of MBT waste in landfills are based on laboratory results. However, several authors (Fellner et al. 2009; Di Maria et al. 2013) have noted that the processes that take place in actual landfills are different. Hence the importance of obtaining field data.

From the first applications of pretreatment as an option to reduce pollution in municipal landfills, numerous studies have been conducted in this field, mainly in Europe. Most of them have dealt with the MBT reject dumped without separation of the organic fraction. Initially the authors centred on evaluating pretreatment systems as decontamination processes. It has been proved experimentally that, because the dumped waste is more degraded, gaseous and liquid contamination is lower and the settlements that take place during the operation are also diminished. Nevertheless, there are still queries, such as the quantification of this reduction in different cases or the assessment of the long-term effect.

The current knowledge on emissions in new MBT landfills can be separated into two interrelated areas: evaluation of liquid pollution and quantification of gaseous emissions. 


\section{Liquid pollution}

Biological pretreatment aims to increase the stability of organic matter by shortening the stages of decomposition in the landfill. Shortly after the waste is buried, leachate characteristics show the end of the acidogenic phase, namely, reduced carbonaceous organic material concentration, low biodegradability (low biochemical oxygen demand (BOD) to chemical oxygen demand (COD) ratio) and $\mathrm{pH}$ close to neutrality (Bone et al. 2003).

Based on laboratory tests and/or field observations, a number of authors (Sormunen et al. 2008; Siddiqui et al. 2012) have demonstrated that leaching of carbonaceous matter can be reduced with MBT by up to $10 \%$ of the initial leachability value, depending on the type and intensity of the previous treatment. In consequence, the organic load (COD, BOD, total organic carbon (TOC)) decreases in the leachate.

The effect of MBT on other contaminants of the leachate is not so well known. In the case of some heavy metals, for example, several authors have not detected differences between fresh and pretreated waste, while others have observed lower leachability in the latter case (Münnich et al. 2006). Nonetheless, a complexation effect of the organic matter (COD) has been discovered, which favours the evolution of some pollutants together over time (Pantini et al. 2015).

Additionally, more research is needed in order to know what happens to the nitrogenous substances. Different authors have pointed out a reduction similar to that shown by carbonaceous compounds (Cappai et al. 2005), but others have measured ammonium concentrations in the leachate that remain high for a long time (Salati et al. 2013).

\section{Gaseous emissions}

The pretreatment of the biodegradable fraction of municipal solid waste (MSW) has been suggested as a method of reducing landfill gas emissions (Donovan et al. 2010). The results of various studies reveal that, because the biodegradable material is more decomposed due to biological pretreatment, the generation of methane is accelerated, thus keeping the trends noted in traditional landfills. Methanization is established early when anaerobic degradation processes are still intense, and reduces gradually in the course of time to very low rates that extend for decades (Cappai et al. 2005). Heyer et al. (2013) proposed the representation of this evolution with a three-phase (slow, intermediate and fast degradation) model; however, other authors obtained good fits with a first-order model in two stages (Di Maria et al. 2013).

In contrast, also in this kind of waste, both temperature and moisture have been proved to be key factors in the development of degradation and therefore in gas generation (Bockreis and Steinberg 2005). 
Potential methane generation may be reduced by up to $90 \%$ through MBT (De Gioannis et al. 2009). But it is still not possible to predict the composition of biogas, and several authors have come to different conclusions. Kuehle-Weidemeier and Doedens (2003) found methane/carbon dioxide $\left(\mathrm{CH}_{4} / \mathrm{CO}_{2}\right)$ ratios similar to those seen in conventional landfills, while Wagner et al. (2007) observed an inverse relationship. Nonetheless, Brockreis and Steinberg (2005) detected $\mathrm{CH}_{4} / \mathrm{CO}_{2}$ ratios that were significantly higher than the usual values, up to $45: 1$, depending on the waste pretreatment.

After observing this decrease in the presence of methane, the study of another important greenhouse gas, $\mathrm{N}_{2} \mathrm{O}$, has begun. In MBT landfills there is an important production associated with nitrification, which starts with the entrance of oxygen when dumping waste in the landfill (Harborth et al. 2013).

Upon comparing waste pretreatment processes, it has been detected that the reduction of the gas potential depends on the duration of the process. Some authors have suggested that if the biological stage is aerobic, it should be extended to around 4 weeks, since a longer treatment diminishes the amount of recoverable gas, thereby increasing the overall environmental impact of the treatment-final disposal solution (Di Maria et al. 2013).

Montejo et al. (2013) confirmed that the behaviour of the MBT waste in the landfill depends on both the process and the origin of the waste. Optimal solutions might be established to minimize the impact of the rejected fraction in landfills, but there are too many differences, due to the diversity of processes and inputs, to find a common solution (Di Lonardo et al. 2012).

These significant differences among MBT processes, together with the disparity of results observed so far, point to the need for further research in this area. Moreover, in spite of the availability of numerous laboratory results, there is a need for field scale studies, especially those based on a comprehensive assessment, considering variables of different nature and their interactions (e.g. hydraulics, degradation, settlement, temperature).

The aim of this research was to study the field behaviour of waste that is characteristic of the rejects generated in MBT similar to those installed in Spain. Other regions, with waste management strategies that tend to send to the landfill only pretreated waste after recovering recyclables, using bio-waste and valorising the fraction with high calorific value, may benefit from the results obtained. The study is based on the construction of a pilot cell from which real scale data could be obtained in a controlled environment. This paper discusses the main results achieved during the first months, which are expected to be the most problematic period for this type of waste, and analyses the practical implications of the operation of this new type of landfills.

\section{MATERIALS AND METHODS}

\section{Pilot-scale cell}

This research is part of a three-year project, which included conventional waste characterization tests, percolation tests and specific tracer tests in laboratory columns on 
different scales, as well as fieldwork. The results of the laboratory tests have been presented in other papers (Molleda et al. 2013; Molleda et al. 2015). The data gathered in the field are analysed in this article.

In order to monitor the behaviour of MBT rejects under landfill conditions, a pilot-scale cell was built during the early months of 2014. The experimental cell is within the area of operation of the Meruelo landfill (Cantabria, Spain), which is part of the Meruelo Environmental Complex.

In Cantabria, the glass, light packaging, and paper and cardboard fractions are collected separately. The complex receives 218,760 t/yr (data from 2014) of rest fraction of municipal waste (mixed materials, not collected separately). This fraction is treated in an MBT plant that obtains as a result several streams of recyclable material recovered from the mixture, including $118,700 \mathrm{t} / \mathrm{yr}$ of waste-derived fuel; 32,500 t/yr of biostabilized material used as a soil conditioner; and 36,000 t/yr of rejects from the refining treatment of this last fraction. The biostabilization process is performed on the material, which passes through a 9-mm trommel screen, in two covered buildings with a combined floor area of $165 \times 35 \mathrm{~m}$. The process lasts 8 weeks, during which the treatment is limited to a weekly turning with an automatic turning machine: there is no addition of water or other elements.

The rejects of the refining stage after biostabilization are sent to the landfill, together with the slag from the energy recovery plant and other waste. Pretreatment rejects represent today approximately $40 \%$ of the total waste reaching the landfill $(100,000 \mathrm{t} / \mathrm{yr})$, but this proportion is expected to rise as the amount of waste subjected to pretreatment increases.

The landfill began a new phase of operation in November 2011. It is located in a sunken area on a former landfill, which had been isolated according to the Council Directive 1999/31/EC (European Council 1999). The material deposited in the new phase is kept completely separated from the previously dumped waste by means of a double-bottom liner that has two clay layers and two high-density polyethylene geomembranes and then a drainage gravel layer followed by a geotextile.

The operating system includes the dumping of compacted waste in layers that are about $4 \mathrm{~m}$ thick, with intermediate clay covers of approximately $30 \mathrm{~cm}$. These layers extend along the entire surface, that is, from the upstream to the landfill retaining wall. In addition to the bottom drainage layer with $50 \mathrm{~cm}$ of gravel and collection pipes, a dendritic drainage network is placed in each layer. This is formed by cross-drains of gravel (parallel to the retaining wall) that lead the leachate to a main pipe which divides the layer into two halves in the direction of the slope. The pipes of each layer are connected to the main pipe through the retaining wall. In this pipe, leachate collected at all layers of the different phases of the landfill is gathered and taken to the regulation pools and, subsequently, for treatment.

In order to minimize the production of contaminated water, as the deposition of waste moves forward in each layer, the dumping area is isolated from the empty areas by means of perimeter ridges that separate the leachate from the clean runoff. This runoff is led to 
the perimeter ditch where, after checking that it is unpolluted in a control concrete pit, it is discharged into the environment.

The collection pipes installed in the first of these phases have been raised through the liner system for biogas collection and extraction. Thus, the gas generated by the new waste is mixed with that generated in the lower layers before being led to the gas treatment and energy production plant.

The total bottom area of the landfill is 7.5 ha, but it is reduced to 0.9 ha in the current operating area.

The footprint of the pilot cell is a square of $30 \times 30 \mathrm{~m}^{2}$. The cell was filled with rejects coming directly from the refining stage (after biostabilization) of the MBT plant until it was four metres high.

A load of 4,966 T of waste with a global moisture of $30 \%$ and the composition shown in Table 1 was introduced into the cell (Molleda et al. 2013), resulting in a dry density of $967 \mathrm{~kg} / \mathrm{m}^{3}$. Table 1 shows that almost $10 \%$ of the waste was classified as unidentified. This category includes inert as well as biodegradable materials that, after undergoing the MBT, could not be identified.

Table 1 Composition of the waste in the pilot-scale cell

\begin{tabular}{lc}
\hline \multicolumn{1}{c}{ Component } & $\begin{array}{c}\text { Fraction of dry matter } \\
(\boldsymbol{\%})\end{array}$ \\
\hline Rigid plastics & 0.8 \\
\hline Flexible plastics & 3.3 \\
\hline Paper and cardboard & 12.1 \\
\hline Textile & 1.3 \\
\hline Wood & 4.1 \\
\hline Shell and seed & 7.0 \\
\hline Bones & 2.0 \\
\hline Metals & 1.5 \\
\hline Glass & 51.5 \\
\hline Stones and ceramics & 6.6 \\
\hline Unidentified $>4 \mathrm{~mm}$ & 3.1 \\
\hline Unidentified $<4 \mathrm{~mm}$ & 6.7 \\
\hline Total & 100 \\
\hline
\end{tabular}

The cell was built on the current operating area of the landfill, on the first waste layer, which was covered by approximately $30 \mathrm{~cm}$ of clay marl. To isolate the cell, both the bottom and the perimeter were covered with a plastic liner protected with a geotextile on the top. The leachate collection system was placed on the geotextile, on the diagonal of the cell and following the slope. This consisted of a coarse aggregate with a perforated plastic tube in its final stretch. Leachate percolates to the bottom of the cell, where it is 
collected by a perforated pipe which in turn conveys it to the leachate sampling point, outside the cell (see Figure 1). Moreover, a $50-\mathrm{cm}$ high perimeter wall was built with the same clay marl aggregate used in other places in the landfill (Figure 1). Once the cell was filled, $30 \mathrm{~cm}$ of the same material was extended over it, mimicking the usual intermediate cover, and a new perimeter wall was placed to collect the runoff and isolate it from the surroundings.

For a detailed follow-up of the evolution of the cell, besides conventional systems for leachate and runoff sampling, several measurement devices for continuous in situ monitoring were installed at various points within the waste. Instrumentation was distributed in three layers and at four points at each level (Figure 1). Every monitoring point was represented by a number indicating its plant position (from 1 to 4), followed by the number corresponding to the depth of the sensor (1 the deepest level, 2 the intermediate and 3 the shallowest one).

Instrumentation included four piezometers (located at the lower level), 12 thermometers (PT100) and 12 gas/liquid samplers. The signals of the thermometers and piezometers were collected and recorded in a data logger every 30 minutes. Samplers were small stretches of handmade perforated tubes connected to the outside by hoses, through which the fluid accumulated in the waste could be drawn by suction. In addition, two flowmeters for continuous monitoring of leachate (PLU-100, Desin Instruments) and runoff flows (Sigma 950, Hach Co.) were installed.

The monitoring plan for the cell at this stage of the research lasted 18 months (535 days). It included the capture and analysis of instrumentation data once a week; monthly sampling and laboratory analyses of the leachate taken from the sampling point and runoff and gas collected in the samplers inside the cell, and a monthly topographical survey of four settlement plates. These instruments consisted of square $1 \mathrm{~m}^{2}$ stainless steel plates with a welded central steel shaft that were custom-manufactured to control settlements. The shafts were extended as the landfill level rose, and acted as the reference rod to be measured periodically by means of topographical surveys.

\section{Laboratory analysis}

The leachate was sampled monthly during the study period at the leachate sampling point, located outside the cell, at the lowest point of the leachate collection pipe. Altogether 17 samples were analysed. Electrical conductivity (EC), $\mathrm{pH}$, redox potential and dissolved oxygen (DO) were measured in situ with portable equipment (CRISON 524 conductivity meter, CRISON $507 \mathrm{pH}$ meter with electrode 52-00 and redox potential electrode and WTW Oxi 330/SET oxygen probe). To preserve the sample, the UNE-EN ISO 5667-3 standard was followed. The leachate parameters analysed in the laboratory were: $\mathrm{pH}, \mathrm{EC}$, dissolved and total COD, dissolved and total biochemical oxygen demand after 5 days $\left(\mathrm{BOD}_{5}\right)$, total nitrogen $(\mathrm{TN})$, ammonia nitrogen $\left(\mathrm{NH}_{4} \_\mathrm{N}\right)$, alkalinity, sulphates, total solids (TS), volatile solids (VS), suspended solids (SS), volatile suspended solids (VSS) and concentrations of several heavy metals. All the analyses were performed according to standardized methods (APHA 2005). 
At the same time leachate samples were taken from the leachate collection system of the landfill where the pilot cell was located. The same parameters were analysed in this leachate to compare the results with those of the cell. The landfill and the cell were subject to the same climatology and similar operation practices (waste compaction, cover) but the former included other types of waste. Comparing the leachate characteristics may help to identify the impact of MBT rejects on the pollution that is generated.

Furthermore, samples were taken every two weeks from the sampling ports installed inside the cell. On four occasions a small amount of liquid was obtained from the sampling ports located in the bottom of the cell (points 2, 3 and 4 at level 1). The rest of the time, only biogas could be found at each point.

Biogas sampling from the inside of the cell was conducted fortnightly. Concentrations of $\mathrm{CH}_{4}, \mathrm{CO}_{2}$, oxygen $\left(\mathrm{O}_{2}\right)$ and hydrogen sulphide $\left(\mathrm{H}_{2} \mathrm{~S}\right)$ were determined using a portable gas analyser (initially GA2000 model and later GA5000, from Geotechnical Instruments, UK).

\section{RESULTS AND DISCUSSION}

\section{Leachate}

\section{Flow rates}

Leachate flow rates showed a rapid response to rain. As water passed through the small height of the cell, much of the infiltrated water quickly collected at the bottom of the cell. This caused a great variability in flows (a range between $5 \mathrm{~L} / \mathrm{h}$ and $100 \mathrm{~L} / \mathrm{h}$ was observed) that could not be recorded by the equipment installed. Therefore, a continuous record throughout the experimentation is not available, but only partial records for a few days. From these it has been estimated that approximately $20 \%$ of the volume of incident rainwater has become leachate.

During the 18 months of follow-up 2,108 $\mathrm{mm}$ of total precipitation and approximately $422 \mathrm{~mm}$ of leachate were recorded, representing a total volume of $379 \mathrm{~m}^{3}$ (an average of $709 \mathrm{~L} / \mathrm{d}$ ). Taking into account all the weight of the dumped waste, at the end of the monitoring period a liquid-solid ratio $(\mathrm{L} / \mathrm{S})$ of $0.11 \mathrm{~L} / \mathrm{kg}$ was obtained.

Moreover, the piezometers occasionally registered some leachate accumulation on the bottom. This coincides with the samples extracted from the sampling ports, which only included leachate in four cases.

\section{Composition}

Table 2 shows the ranges of variation of parameters throughout the study: those noted in "conventional" young (acid phase) and old (methanogenic phase) landfills; the values proposed for MBT waste with different degrees of composting pretreatment; and, finally, the results achieved for the overall leachate collected in the landfill. 
Table 2 Leachate quality results versus values published in literature

\begin{tabular}{|c|c|c|c|c|c|c|c|c|}
\hline \multirow[b]{2}{*}{ PARAMETER } & \multirow[b]{2}{*}{ UNITS } & \multirow[b]{2}{*}{$\begin{array}{c}\text { Pilot-scale cell a } \\
\text { (17 samples) }\end{array}$} & \multirow[b]{2}{*}{$\begin{array}{l}\text { Meruelo landfill a } \\
\text { (17 samples) }\end{array}$} & \multicolumn{3}{|c|}{ Christensen et al. 2001} & \multicolumn{2}{|c|}{ Robinson et al. 2005} \\
\hline & & & & Acid phase & $\begin{array}{l}\text { Methanogenic } \\
\text { phase }\end{array}$ & $\begin{array}{l}\text { Landfill } \\
\text { leachate }\end{array}$ & $\begin{array}{c}\text { MBT High } \\
\text { degree of } \\
\text { composting }\end{array}$ & $\begin{array}{c}\text { MBT Low- } \\
\text { medium degree } \\
\text { of composting }\end{array}$ \\
\hline pH & & $7.9-9.6(8.9)$ & $7.4-8.6(8.0)$ & $4.5-7.5$ & $7.5-9$ & $4.5-9$ & $7.5-8$ & $7.5-8.5$ \\
\hline Conductivity & $\mathrm{mS} / \mathrm{cm}$ & $31.5-67.8(46.8)$ & $6.6-22.3(13.7)$ & & & & $6-10$ & $10-20$ \\
\hline Total COD & $\mathrm{mg} / \mathrm{L}$ & $10833-79478(29981)$ & $1037-11013$ (2894) & & & & & \\
\hline Dissolved COD & $\mathrm{mg} / \mathrm{L}$ & $9943-72912(25858)$ & 843-10771 (2535) & $6000-60000$ & $500-4500$ & $140-152000$ & $2000-1500$ & $1000-5000$ \\
\hline Total BOD5 & $\mathrm{mg} / \mathrm{L}$ & $850-20400(6700)$ & $160-4400(984)$ & & & & & \\
\hline Dissolved $\mathrm{BOD}_{5}$ & $\mathrm{mg} / \mathrm{L}$ & $200-16000(5100)$ & $120-2900(722)$ & $4000-40000$ & $20-550$ & $20-57000$ & $50-30$ & $20-200$ \\
\hline Dissolved TOC & $\mathrm{mg} / \mathrm{L}$ & $2736-27395(8560)$ & $263-5151(970)$ & & & $30-29000$ & $500-500$ & $500-2000$ \\
\hline $\mathrm{NH}_{4}-\mathrm{N}$ & $\mathrm{mg} / \mathrm{L}$ & $1378-5600(3420)$ & $323-1230(667)$ & & & $50-2200$ & $30-200$ & $50-1000$ \\
\hline Sulphates (as $\left.\mathrm{SO}_{4}\right)$ & $\mathrm{mg} / \mathrm{L}$ & $88-2179(937)$ & 57-332 (150) & $70-1750$ & $10-420$ & 8-7750 & $500-500$ & $1000-5000$ \\
\hline Total Solids & $\mathrm{mg} / \mathrm{L}$ & $22258-138706(46100)$ & $4010-13770(7238)$ & & & $2000-60000$ & & \\
\hline Calcium & $\mathrm{mg} / \mathrm{L}$ & 9-917 (180) & $83-287(147)$ & $10-2500$ & $20-600$ & $10-7200$ & $250-300$ & $100-800$ \\
\hline Sodium & $\mathrm{mg} / \mathrm{L}$ & $3485-7043(5326)$ & $612-2600(1407)$ & & & $70-7700$ & $800-1200$ & $2000-4000$ \\
\hline Magnesium & $\mathrm{mg} / \mathrm{L}$ & $38-793(163)$ & 43-131 (69) & $50-1150$ & $40-350$ & $30-15000$ & $60-100$ & $100-400$ \\
\hline Iron & $\mathrm{mg} / \mathrm{L}$ & $7-40(16)$ & 2-11 (3) & & & $3-5500$ & 2-10 & $5-20$ \\
\hline Chromium & $\mu \mathrm{g} / \mathrm{L}$ & $209-1180(746)$ & $<44-259(156)$ & & & $20-1500$ & $50-100$ & $100-500$ \\
\hline Cadmium & $\mu \mathrm{g} / \mathrm{L}$ & 4-287 (55) & $<1-21(11)$ & & & $0.1-400$ & 3-3 & $5-100$ \\
\hline Copper & $\mu \mathrm{g} / \mathrm{L}$ & $747-10422(2140)$ & $52-238(115)$ & & & 5-10000 & $200-200$ & $200-500$ \\
\hline Zinc & $\mu \mathrm{g} / \mathrm{L}$ & $1500-18584(4083)$ & $104-4794(615)$ & $100-120000$ & $30-4000$ & $30-1000000$ & $500-200$ & $500-3000$ \\
\hline Lead & $\mu \mathrm{g} / \mathrm{L}$ & $88-1626(437)$ & $<8-231(63)$ & & & $1-5000$ & $20-40$ & $100-400$ \\
\hline Nickel & $\mu \mathrm{g} / \mathrm{L}$ & $88-3331(1582)$ & $77-460(198)$ & & & $15-13000$ & $100-100$ & $100-700$ \\
\hline Arsenic & $\mu \mathrm{g} / \mathrm{L}$ & $290-630(463)$ & 26-110 (61) & & & $10-1000$ & 4-6 & $10-100$ \\
\hline Mercury & $\mu \mathrm{g} / \mathrm{L}$ & $0.9-5.0(1.8)$ & $<0.5-0.8(<0.5)$ & & & $0.1-160$ & $0.1-0.1$ & $0.1-10$ \\
\hline
\end{tabular}

${ }^{a}$ Values in parentheses indicate the average value found for each parameter.

${ }^{b}$ The first number corresponds to the initial value, typically up to 2-3 years. The second number refers to later measurements. 
The basic $\mathrm{pH}$ of the leachate, above 8 from the early months onwards, is typical of a mature landfill, where the waste is quite degraded. However, it does not correspond with that observed in the laboratory. Several percolation tests were performed according to CEN/TS 14405:2004 and in all cases initial $\mathrm{pH}$ values below 7 were obtained, mostly around 6.5 (Molleda et al. 2015). This observation agrees with previous findings as in Pantini et al. (2015), who detected pH values varying between 6 and 7 in different percolation tests with MBT from an Italian plant. This difference may be a consequence of the different conditions in the laboratory (higher L/S ratio, 24 hours contact time, etc.). However, it could also indicate that some materials used in landfills, such as drainage aggregates or soil coverage, alter the composition of the leachate generated. It highlights the fact that laboratory results cannot be translated to the field directly. Nevertheless, Salati et al. (2013) also found slightly acidic $\mathrm{pH}$ in the first months of laboratory tests, which simulated landfill conditions in the laboratory with organic waste treated aerobically for 28 days, but $\mathrm{pH}$ stabilized at above 7 when the acid concentration in the leachate decreased. Robinson et al. (2005), in turn, also found basic $\mathrm{pH}$ in all MBT landfills studied, with values of 7.9 where the waste had undergone a pretreatment similar to that of Meruelo, and even higher than 8 , where the waste had received a higher degree of pretreatment.

High concentrations of dissolved solids (DS), organic compounds (COD, BOD, TOC) and especially ammonia nitrogen show that the waste is not yet stabilized. Conversely, although a general downward trend over time is detected, there were notable variations due to dilution during rain events.

Both measured DS and EC, with a mean value of $46.8 \mathrm{mS} / \mathrm{cm}$, are within the range of the typical values for conventional landfills with untreated waste.

EC is also in the order of the values pointed out by Münnich et al. (2011) in an experimental MBT waste cell, but well above the values found by other authors. It is for example more than twice the values measured by Siddiqui et al. (2012) in their Consolidating Anaerobic Reactors (CAR) tests with two types of MBT, where the less stable waste, subjected to recirculation, peaked at $20 \mathrm{mS} / \mathrm{cm}$. This large difference can be attributed in part to the effect of several dilutions, since Siddiqui et al. (2012) worked with $\mathrm{L} / \mathrm{S}$ ratios of $2 \mathrm{~L} / \mathrm{kg}$, whereas in this study the cell only reached $0.11 \mathrm{~L} / \mathrm{kg}$ at the end of the experimental period. As shown in Figure 2, after the first few months, when the highest values are maintained, conductivity decreases as the waste is washed.

Fellner et al. (2009) revealed that, as a rule, EC is directly related to the concentration of chlorides $(\mathrm{Cl})$ in leachates. These authors studied an old conventional waste landfill since its opening in 1987, and in the early years they obtained maximum $\mathrm{Cl}$ values of 5,000 $\mathrm{mg} / \mathrm{L}$, that is, less than half the maximum concentrations in this work $(13,500 \mathrm{mg} / \mathrm{L})$. As a reference, Robinson et al. (2005) suggested up to $8,000 \mathrm{mg} \mathrm{Cl} / \mathrm{L}$ for $\mathrm{MBT}$ waste leachate with a low degree of composting, which is close to the noted value.

In relation to the mass of waste, for the same L/S ratio as this study, Fellner et al. (2009) observed a release of $300 \mathrm{mg} \mathrm{Cl} / \mathrm{kg}$ dry matter (DM) in conventional waste, while in this research the ratio is twice that value: $600 \mathrm{mg} \mathrm{Cl} / \mathrm{kg} \mathrm{DM}$ (see Table 3). This difference indicates the effect of pretreatment: it makes the degraded compounds readily available (facilitating their dissolution when they come into contact with water), to the extent that 
they appear in the early stages of leachate, increasing the rate of release (doubling it in this case).

The most abundant cations in the collected leachate were sodium $(\mathrm{Na})$, calcium $(\mathrm{Ca})$ and magnesium $(\mathrm{Mg})$, with mean concentrations during the study period of 5,326 mg/L, 180 $\mathrm{mg} / \mathrm{L}$ and $163 \mathrm{mg} / \mathrm{L}$ respectively. This order of abundance coincides with the one of Robinson et al. (2005), who noted values of 1,250 mg/L, $329 \mathrm{mg} / \mathrm{L}$ and $104 \mathrm{mg} / \mathrm{L}$ for Na, $\mathrm{Ca}$ and $\mathrm{Mg}$ in waste after passive windrow composting, and the one by Pantini et al. (2015), who observed a release of $5.6 \mathrm{~g} \mathrm{Ca} / \mathrm{kg} \mathrm{DM}, 3.6 \mathrm{~g} \mathrm{Na} / \mathrm{kg} \mathrm{DM}$ and $0.6 \mathrm{~g} \mathrm{Mg} / \mathrm{kg}$ $\mathrm{DM}$ for an L/S ratio of 10 . In the present work, accumulated values reached $0.522 \mathrm{~g} \mathrm{Na}$ /kg DM, $0.013 \mathrm{~g} \mathrm{Ca} / \mathrm{kg}$ DM and 0.015 g Mg/kg DM (Table 3).

Table 3. Release of contaminants

\begin{tabular}{lccc}
\hline & & Pilot cell & Pantini et al. 2015 \\
\cline { 3 - 4 } PARAMETER & UNIT & L/S 0.11 & L/S 10 \\
\hline pH & & $9.6-7.9(8.9)$ & 6.5 \\
Conductivity & $\mathrm{mS} / \mathrm{cm}$ & $67.8-31.5(46.8)$ & \\
Dissolved COD & $\mathrm{mg} / \mathrm{kg} \mathrm{DM}$ & 2496 & \\
Dissolved TOC & $\mathrm{mg} / \mathrm{kg} \mathrm{DM}$ & 857 & 14800 \\
Chlorides & $\mathrm{mg} / \mathrm{kg} \mathrm{DM}$ & 602 & 7300 \\
NH4-N & $\mathrm{mg} / \mathrm{kg} \mathrm{DM}$ & 418 & \\
Sulphates & $\mathrm{mg} / \mathrm{kg} \mathrm{DM}$ & 56 & \\
Calcium & $\mathrm{mg} / \mathrm{kg} \mathrm{DM}$ & 12.9 & 5600 \\
Sodium & $\mathrm{mg} / \mathrm{kg} \mathrm{DM}$ & 522 & 3600 \\
Magnesium & $\mathrm{mg} / \mathrm{kg} \mathrm{DM}$ & 14.8 & 600 \\
Iron & $\mathrm{mg} / \mathrm{kg} \mathrm{DM}$ & 1.52 & 60 \\
Chromium & $\mathrm{mg} / \mathrm{kg} \mathrm{DM}$ & 0.091 & 0.76 \\
Cadmium & $\mathrm{mg} / \mathrm{kg} \mathrm{DM}$ & 0.005 & \\
Copper & $\mathrm{mg} / \mathrm{kg} \mathrm{DM}$ & 0.203 & 6.26 \\
Zinc & $\mathrm{mg} / \mathrm{kg} \mathrm{DM}$ & 0.427 & 38.3 \\
Lead & $\mathrm{mg} / \mathrm{kg} \mathrm{DM}$ & 0.038 & 2.9 \\
Nickel & $\mathrm{mg} / \mathrm{kg} \mathrm{DM}$ & 0.177 & 2.4 \\
Arsenic & $\mathrm{mg} / \mathrm{kg} \mathrm{DM}$ & 0.018 & \\
Mercury & $\mu \mathrm{gg} / \mathrm{kg} \mathrm{DM}$ & 0.057 & \\
\hline
\end{tabular}

The concentrations of the metals that were measured (Table 2) are also higher than those in other references. The concentrations reached by iron $(\mathrm{Fe})$, copper $(\mathrm{Cu})$, zinc $(\mathrm{Zn})$ and nickel (Ni) stand out above the rest. In their work on the leaching of metals in MBT waste in laboratory columns, Pantini et al. (2015) obtained maximum release rates (for $\mathrm{L} / \mathrm{S}=$ $10 \mathrm{~L} / \mathrm{kg}$ ) of $70 \mathrm{mg} / \mathrm{kg} \mathrm{DM}, 6 \mathrm{mg} / \mathrm{kg} \mathrm{DM}, 45 \mathrm{mg} / \mathrm{kg} \mathrm{DM}$ and $2.5 \mathrm{mg} / \mathrm{kg} \mathrm{DM}$ for Fe, $\mathrm{Cu}$, $\mathrm{Zn}$ and $\mathrm{Ni}$ respectively. The values achieved in this research, $1.52 \mathrm{mg} F / \mathrm{kg} \mathrm{DM}, 0.20$ $\mathrm{mg} \mathrm{Cu} / \mathrm{kg} \mathrm{DM}, 0.43 \mathrm{mg} \mathrm{Zn/kg} \mathrm{DM}$ and $0.18 \mathrm{mg} \mathrm{Ni} / \mathrm{kg} \mathrm{DM}$, are much lower than both 
these and the values the authors obtained for $\mathrm{L} / \mathrm{S}=0.1 \mathrm{~L} / \mathrm{kg}$. These differences can be attributed to the fact that the waste tested in the above-mentioned work experienced a shorter, although more intense, treatment (28 days with forced aeration, watering and daily turning) than the waste studied here, and also to the influence of $\mathrm{pH}$. In their study, $\mathrm{pH}$ is slightly acidic, which increases the solubility of metals as compared to this study. The concentrations of many of the contaminants decreased to less than one-third of the initial value after the first nine months, thus showing the washing effect.

In all measured cations, such as $\mathrm{Fe}, \mathrm{Ni}, \mathrm{Mg}$ and $\mathrm{Ca}$, concentrations also maintained a downward trend (Figure 3a). The mass release curves (Figure 3b) show how, in March 2015, the release of these elements slowed down, coinciding with the increase in $\mathrm{pH}$, which exceeded 9 in April of the same year. This effect is especially noticeable in the case of $\mathrm{Ca}$, the release of which does not exceed $13 \mathrm{mg} / \mathrm{kg} \mathrm{DM}$ at the end of the period. However, in the laboratory leaching tests, Ca releases of about 2,200 mg/kg DM were obtained (data not shown here). This seems to indicate that the low concentrations at the end of the monitoring period are influenced by the low solubility of these cations at high $\mathrm{pH}$. This effect must be considered in the design of the leachate collection system, since the formation of precipitates in these conditions could clog the pipes.

Decline over time is more pronounced for the organic components (Figure 4), which is the result of an active degradation also reflected in the biogas, as described in the next section. The measured values of COD $(72,000 \mathrm{mg} / \mathrm{L})$, TOC $(27,000 \mathrm{mg} / \mathrm{L})$ and BOD $(16,000 \mathrm{mg} / \mathrm{L})$ initially exceed the ranges of waste with low-medium pretreatment, with maximum values of 5,000 mg/L, 2,000 mg/L and $200 \mathrm{mg} / \mathrm{L}$ respectively (see Table 2). These parameters remain at high levels and even increase during the first weeks and then descend drastically when methanization becomes predominant. This causes the reduction of BOD concentrations by two orders of magnitude, with final values of $200 \mathrm{mg} / \mathrm{L}$ in the monitoring period.

The average concentrations of COD observed in this study are consistent with those achieved by Suchowska-Kisielewicz et al. (2013), who reported values of 23,500 mg/L during the unstable methanogenic phase. Taking these authors' results into account, the stable phase (in which measured COD concentrations were $1,300 \mathrm{mg} / \mathrm{L}$ ) has not yet been reached in this research.

The TOC concentrations noted in this work coincide with those obtained for low L/S by Pantini et al. (2015) in their MBT tests. In the experimental period, the total TOC released, $857 \mathrm{mg} / \mathrm{kg} \mathrm{DM}$, is within the range of that detected by Fellner et al. (2009) for similar $\mathrm{L} / \mathrm{S}$ ratios in a conventional landfill during the acidogenic phase.

The case of ammonia nitrogen is noteworthy as, despite an initial decrease (see Figure $4 c$ ), it maintains concentrations above those achieved by other authors. Robinson et al. (2005), for example, obtained similar concentrations in landfills with fresh organic matter, but lower values, from 50 to $1,000 \mathrm{mg} \mathrm{NH}_{4}-\mathrm{N} / \mathrm{L}$, in leachate generated from waste subjected to low-intensity aerobic pretreatment.

If the evolution of ammonia nitrogen is compared to that of BOD, a slightly smaller drop is observed in the first case. This may be the result of a slower release of the compound coupled with its permanence in the leachate, since, in contrast to the carbonaceous material, nitrogen is not turned into biogas. On another note, there is also agreement on 
the idea that one of the expected benefits of the biological pretreatment of waste is the reduction of the nitrogen pollution load in landfills (Siddiqui et al. 2012).

The main cause of the high concentrations of ammonia noted at the beginning of the monitoring of the cell can be the ammonification of organic nitrogen in the MBT plant, leaving a large amount of ammonia nitrogen available. Because the waste does not undergo a maturation process that would promote its nitrification, it is released as of the moment when waste is dumped. Siddiqui et al. (2012) observed a similar effect, i.e. a quick release, in their laboratory study, but they reached $\mathrm{NH}_{4}-\mathrm{N}$ concentrations only slightly above $1,000 \mathrm{mg} / \mathrm{L}$ in the least stabilized waste. However, although the $\mathrm{L} / \mathrm{S}$ ratio of $2 \mathrm{~L} / \mathrm{kg}$ used by these authors was higher than the one in this study, the amounts of nitrogen released in their experiments -850 and $390 \mathrm{mg} / \mathrm{kg} \mathrm{DM}$ for each of the mechanically-biologically pretreated samples of waste - are close to those obtained here: $420 \mathrm{mg} / \mathrm{kg}$ DM. In their study with old conventional waste, Fellner et al. (2009) achieved lower releases, below $150 \mathrm{mg} / \mathrm{kg} \mathrm{DM}$ of $\mathrm{NH}_{4}-\mathrm{N}$ with $\mathrm{L} / \mathrm{S}$ ratios similar to those in this research. As these authors pointed out, these large differences are affected by the nature of the waste, by the distribution of the water flow, which, not being homogeneous, determines the actual L/S ratio in the landfill, and by the moisture at different points, which also modifies biological rates.

\section{Comparison with the landfill}

The leachate from the cell has significantly higher concentrations than those from the landfill in which it is located (Table 2). The reason for this is twofold. First, the landfill has a much larger area exposed to rain, which facilitates greater dilution. Furthermore, the landfill is older than the cell, since it began operation in 2011, and therefore the waste, which also includes a non-pretreated conventional urban waste fraction, has undergone a longer stabilization process. The average concentrations of various inorganic parameters in the landfill leachate remain between $10 \%$ and $30 \%$ of the values measured in the cell leachate. Exceptions are $\mathrm{Ca}$, whose mean concentration in the landfill leachate is $80 \%$ that of the cell leachate $(147 \mathrm{mg} / \mathrm{L}$ versus $180 \mathrm{mg} / \mathrm{L})$, and $\mathrm{Cu}$, with a concentration of $5 \%$ of that of the cell leachate $(0.12 \mathrm{mg} / \mathrm{L}$ versus $2.14 \mathrm{mg} / \mathrm{L})$. The slight difference in $\mathrm{Ca}$ concentrations is explained by the effect of $\mathrm{pH}$ on its solubility. The reduction of $\mathrm{Ca}$ solubility is significantly higher in the cell leachate, as $\mathrm{pH}$ values above 9 have been measured, compared to a maximum of 8.6 in the landfill leachate.

On a different note, $\mathrm{Cu}$ is one of the metals that is most affected by complexation processes with organic compounds. In addition, complexation of $\mathrm{Cu}$ increases dramatically with $\mathrm{pH}$, leading to the highest overall migration velocities for $\mathrm{Cu}$ at high $\mathrm{pH}$ values (Christensen et al. 2001). This could explain the great difference between $\mathrm{Cu}$ concentrations in the leachate of the cell and of the landfill, since no significant differences were identified with regard to the $\mathrm{Cu}$ content between the waste dumped in the landfill and the material in the cell.

As regards organic matter (COD, BOD), there is a greater difference between the average values. As shown in Figure 4a, b, during the first months of degradation concentrations in the cell are very high, but immediately they are reduced to values similar to those in the overall landfill. This indicates the rapid initial stabilization of organic waste. 
All this reveals that the waste in the cell contributes to leachate pollution in a similar way to the rest of the landfill and underlines the possible influence of the $\mathrm{pH}$ of the leachate, as it seems to modify its content.

\section{Instrumentation}

\section{Gases}

Figure 5 shows the composition of the gas collected in the samplers located at different heights at point 1 , within the cell. Similar trends were recorded at the other points (data not shown), except for the points resting on the bottom, which were filled with water from April 2015 onwards and, hence, from then on did not allow gas extraction.

Gas composition is similar at all levels. The $\mathrm{CH}_{4}$ concentration exceeds that of $\mathrm{CO}_{2}$ in the same month (July 2014) as the cell is closed, which reveals that methanogenesis has already been established. Hence, in this type of landfills waste should be covered early and, where appropriate, gas collection equipment should be installed in coordination with the advance of the working face.

The $\mathrm{CH}_{4} / \mathrm{CO}_{2}$ ratio (slightly below 60/40) remains within the usual range of fresh waste landfills in the methanogenic phase.

Figure $5 b$ presents the measured concentrations of $\mathrm{H}_{2} \mathrm{~S}$ and $\mathrm{H}_{2}$. In April 2015 the portable measuring equipment GA2000 was replaced by the GA5000 model. The first had an upper detection limit of $500 \mathrm{ppm}$ for $\mathrm{H}_{2} \mathrm{~S}$ and could not measure hydrogen, while the detection limit of the second one is $5,000 \mathrm{ppm}$ and is capable of detecting hydrogen up to 1,000 ppm. For this reason $\mathrm{H}_{2}$ concentrations only appear at the end of the graphs, and values of $\mathrm{H}_{2} \mathrm{~S}$ above 500 ppm prior to 15 April 2015 are not included. Despite a clear downward trend in the concentration of $\mathrm{H}_{2} \mathrm{~S}$, a definite trend cannot be identified in $\mathrm{H}_{2}$. The stratification of concentrations, in keeping with the density of each compound, is noteworthy in both cases. $\mathrm{H}_{2} \mathrm{~S}$ concentration varies, exceeding 1,500 ppm at the lower level, 1,000 ppm at the intermediate one, and not reaching $50 \mathrm{ppm}$ at the top level. These concentrations surpass the odour threshold of the compound, estimated to be between 0.02 and $0.13 \mathrm{ppm}$ but are well below those measured in construction and demolition (C\&D) debris landfills, with values up to $12,000 \mathrm{ppm}$ (Lee et al. 2006). $\mathrm{H}_{2}$ showed maximum concentrations of approximately 50,100 and $500 \mathrm{ppm}$ at the lower, middle and upper levels, respectively.

\section{Other parameters}

Regarding settlement, monitoring data were used to estimate an average settlement in the cell of $4 \mathrm{~cm}$ ( $1 \%$ of the thickness of the cell) during the first months of operation, without any overload on top of the waste cell.

Figure 6 shows the temperature records of the PT100 probes in contact with the waste at different depths at points 2 and 4 during the first months of follow-up, compared to the ambient temperature in the landfill.

The rejects from the refining treatment are taken to the landfill immediately after MBT, in which temperatures above $60^{\circ} \mathrm{C}$ are reached. This explains the high temperatures recorded since the construction of the pilot cell, with an initial increase favoured by 
aerobic conditions existing at the beginning (Yeşiller et al. 2005). Nevertheless, while thermometers located at the bottom remained at high values, the rest record a continuous drop in temperature, caused by the influence of the contour. This effect is more evident at points 3 (not shown here) and 4 because they are closer to the perimeter of the cell in contact with air (the rest are confined between landfill waste). In an actual facility, this contour effect will have less influence, due to the greater isolation favoured by a larger surface and a higher burial depth.

These high temperatures may be an operational advantage for this type of landfills. Several authors have observed that the optimal range for the conditions of degradation in landfills is around 30 to $45^{\circ} \mathrm{C}$ (Zhao et al. 2016). For example, when modifying operating practices at the landfill (intermediate coverage, layer heights, etc.), high temperatures can be promoted to accelerate degradation. Relevant effects that should be tackled in this case would be the increase of gaseous emissions including organic volatile compounds or nitrogen oxides, enhanced by high temperatures, and the impact on the geomembrane durability (Bouazza et al. 2011). In addition temperatures would have to be mitigated in case of fire risk.

\section{CONCLUSIONS}

Some field results on the behaviour of a landfill for rejects of MBT are presented in this paper. The study includes the first stages in the life of the landfill (18 months). Instrument monitoring and a detailed follow-up have allowed useful information to be obtained with implications for the short-term operation of facilities which receive this kind of waste.

It has been proved that biological pretreatment does not stabilize the organic fraction completely in this case. The waste studied has been subjected to a low-intensity fermentation treatment without undergoing a maturation process. This pretreatment leaves a significant amount of contaminants in the waste, and thus available to be swept by the landfill leachate.

As for organic matter in the leachate (COD, BOD, TOC), the concentrations that have been measured throughout the research are similar to those noted by other authors who studied little-stabilized waste. Nevertheless, at the beginning of the dumping, they exceed the reference ranges which some of them propose for waste that has undergone low-tomedium degree pretreatment. The $\mathrm{NH}_{4}-\mathrm{N}$ concentrations stand out and can be compared to those measured in fresh waste. $\mathrm{pH}$ values seem to have influenced concentrations of some pollutants in the leachate. The washing of contaminants occurs quickly and concentrations are therefore reduced below one-third of the initial values in less than 9 months. With regard to gas, a rapid onset of methanogenic conditions (in less than one month) has been observed. The quick pollutant release means a decline in the long-term remaining pollution, which is in fact the main reason for the pretreatment.

From the obtained information, several proposals for the management of this type of landfill can be derived. First, pretreatment brings about an important reduction in volume, which will extend the useful life of the landfill. Another consideration is that, if regulations regarding emissions from landfills were highly restrictive, a biological 
treatment like the one studied here should be intensified, to further stabilize the residue. Otherwise, the design and operation of the landfills for this MBT waste must be adjusted to its pollution potential.

The dramatic change in the characteristics of the leachate during the first months modifies the ideal treatment conditions for decontamination. This implies that initially the leachate treatment could incorporate a biological treatment to reduce the high concentrations of organic pollution including, from the beginning stages, biological or physicochemical processes to remove nitrogen. After the first landfill stages, the treatment must be adapted to less biodegradable contaminants, with lower but still high ammonia nitrogen concentration.

If the intention is to use the remaining gas potential, the installation of gas collection equipment in coordination with the advance of the working face should be considered. In any case, it is important to cover waste early in order to control emissions.

Finally, the high temperature of the reject dumped, which could even be promoted through operating practices such as intermediate coverage, can favour rapid degradation conditions. However, some drawbacks such as a potential increase in gaseous emissions or possible impacts on the liner must be taken into account.

\section{ACKNOWLEDGEMENTS}

This work is funded by the Spanish Ministry of Economics and Competitiveness through the CTM2012-35055 project. The project is financed jointly by the European Regional Development Fund, FEDER (operational period 2007-2013). The authors wish to thank the Government of Cantabria, through the public company MARE, and TirCantabria, the landfill operator company, for their collaboration.

\section{REFERENCES}

APHA (2005) Standard Methods for the Examination of Water and Wastewater, 21th ed. American Public Health Association, Washington DC.

Bockreis A, Steinberg I (2005) Influence of mechanical-biological waste pre-treatment methods on the gas formation in landfills. Waste Manag 25:337-343. doi:10.1016/j.wasman.2005.02.004.

Bone BD, Knox K, Picken A, Robinson HD (2003) The effect of mechanical and biological pretreatment on landfill leachate quality. In: Proceedings Sardinia 2003, Ninth International Waste Management and Landfill Symposium. CISA, Environmental Sanitary Engineering Centre, S. Margherita di Pula, Cagliari, Italy.

Bouazza A, Nahlawi H, Aylward M (2011) In situ temperature monitoring in an organicwaste landfill cell. J. Geotech. Geoenviron. Eng. 137:1286-1289.

Cappai G, Carucci A, Gioannis GDE, Muntoni A (2005) Further Investigations on Mbp and Relative Implications. In: Proceedings Sardinia 2005, Tenth International Waste Management and Landfill Symposium. CISA, Environmental Sanitary Engineering Centre, S. Margherita di Pula, Cagliari, Italy. 
Christensen TH, Kjeldsen P, Bjerg PL, Jensen DL, Christensen JB, Baun A, Albrechtsen H, Heron G (2001) Biogeochemistry of land leachate plumes. Appl. Geochemistry 16:659-718.

De Gioannis G, Muntoni A, Cappai G, Milia S (2009) Landfill gas generation after mechanical biological treatment of municipal solid waste. Estimation of gas generation rate constants. Waste Manag 29:1026-1034. doi:10.1016/j.wasman.2008.08.016.

Di Lonardo MC, Lombardi F, Gavasci R (2012) Characterization of MBT plants input and outputs: A review. Rev Environ Sci Biotechnol 11:353-363. doi:10.1007/s11157-012-9299-2

Di Maria F, Sordi A, Micale C (2013) Experimental and life cycle assessment analysis of gas emission from mechanically-biologically pretreated waste in a landfill with energy recovery. Waste Manag 33:2557-2567. doi:10.1016/j.wasman.2013.07.011.

Donovan SM, Bateson T, Gronow JR, Voulvoulis N (2010) Modelling the behaviour of mechanical biological treatment outputs in landfills using the GasSim model. Sci Total Environ 408:1979-1984. doi:10.1016/j.scitotenv.2009.12.011.

European Council (2008) Directive 2008/98/CE of the European Parliament and of the Council of 19 November 2008 on waste and repealing certain Directives. Off J Eur Union L312.

European Council (1999) Directive 1999/31/EC on the landfill of waste. Off J Eur Union L 182:1-19.

Fellner J, Döberl G, Allgaier G, Brunner PH (2009) Comparing field investigations with laboratory models to predict landfill leachate emissions. Waste Manag 29:18441851. doi:10.1016/j.wasman.2008.12.022.

Harborth P, Fuß R, Münnich K, Flessa H, Fricke K (2013) Spatial variability of nitrous oxide and methane emissions from an MBT landfill in operation: Strong N2O hotspots at the working face. Waste Manag 33:2099-2107. doi:10.1016/j.wasman.2013.01.028.

Heyer KU, Hupe K, Stegmann R (2013) Methane emissions from MBT landfills. Waste Manag 33:1853-1860. doi:10.1016/j.wasman.2013.05.012.

Kuehle-Weidemeier M., Doedens H (2003) Landfilling and properties of MBP waste. In: Proceedings Sardinia 2003, Ninth International Waste Management and Landfill Symposium. CISA, Environmental Sanitary Engineering Centre, S. Margherita di Pula, Cagliari, Italy.

Lee S, Xu Q, Booth M, Townsend TG, Chadik P, Bitton G (2006) Reduced sulfur compounds in gas from construction and demolition debris landfills. Waste Manag 26:526-533. doi:10.1016/j.wasman.2005.10.010.

Molleda A, López A, Lobo A (2013) Características del rechazo de plantas de tratamiento mecánico-biológico: dos casos en España. In: V Simposio Internacional de Ingeniería de Residuos REDIGIRS- REDISA 2013. Hacia Un Sistema de Gestión Integral de Los Residuos Sólidos. Mendoza, Argentina. 
Molleda A, Woodman N, Stringfellow A, Lobo A (2015) Scale effect in the pollutants transport through the reject of a MBT plan. In: The 6th International Workshop "Hydro-Physico-Mechanics of Landfills." Delft, the Netherlands.

Montejo C, Tonini D, Márquez MC, Astrup TF (2013) Mechanical-biological treatment: Performance and potentials. An LCA of 8 MBT plants including waste characterization. $\mathrm{J}$ Environ Manage 128:661-673. doi:10.1016/j.jenvman.2013.05.063.

Münnich K, Bauer J (2011) Monitoring of MBT material deposited on landfill test areas. In: Fourth International Workshop "Hydro-Physico-Mechanics of Landfills." Santander, Spain.

Münnich K, Mahler CF, Fricke K (2006) Pilot project of mechanical-biological treatment of waste in Brazil. Waste Manag 26:150-157. doi:10.1016/j.wasman.2005.07.022.

Pantini S, Verginelli I, Lombardi F (2015) Analysis and modeling of metals release from MBT wastes through batch and up-flow column tests. Waste Manag 38:22-32. doi:10.1016/j.wasman.2014.12.002.

Robinson HD, Knox K, Bone BD, Picken A (2005) Leachate quality from landfilled MBT waste. Waste Manag 25:383-391. doi:10.1016/j.wasman.2005.02.003

Salati S, Scaglia B, Di Gregorio A, Carrera A, Adani F (2013) The use of the dynamic respiration index to predict the potential MSW-leachate impacts after short term mechanical biological treatment. Bioresour Technol 128:351-358. doi:10.1016/j.biortech.2012.10.101.

Siddiqui AA, Richards DJ, Powrie W (2012) Investigations into the landfill behaviour of pretreated wastes. Waste Manag 32:1420-1426. doi:10.1016/j.wasman.2012.03.016.

Sormunen K, Einola J, Ettala M, Rintala J (2008) Leachate and gaseous emissions from initial phases of landfilling mechanically and mechanically-biologically treated municipal solid waste residuals. Bioresour Technol 99:2399-2409. doi:10.1016/j.biortech.2007.05.009.

Suchowska-Kisielewicz M, Jeddrczak A, Sadecka Z, Myszograj S (2013) Effect of aerobic pretreatment of waste on the rate of anaerobic treatment processes. J Mater Cycles Waste Manag 15:138-145.

Wagner J, Rettenberger G, Reinert P (2007) Modern Landfill Technology - Landfill Behavior of Mechanical- Biological Pre-Treated Waste. In: Proceedings Sardinia 2007, Eleventh International Waste Management and Landfill Symposium. CISA, Environmental Sanitary Engineering Centre, S. Margherita di Pula, Cagliari, Italy.

Yeşiller N, Hanson JL, Liu WL (2005) Heat Generation in Municipal Solid Waste Landfills. J Geotech Geoenvironmental Eng 131:1330-1344. doi:10.1061/(ASCE)1090-0241(2005)131:11(1330).

Zhao YR, Liu TJ, Chen XS, Xie Q, Huang LP (2016) The effect of temperature on the biodegradation properties of municipal solid waste. Waste Manag Res 34:265-274. doi:10.1177/0734242X15622811. 

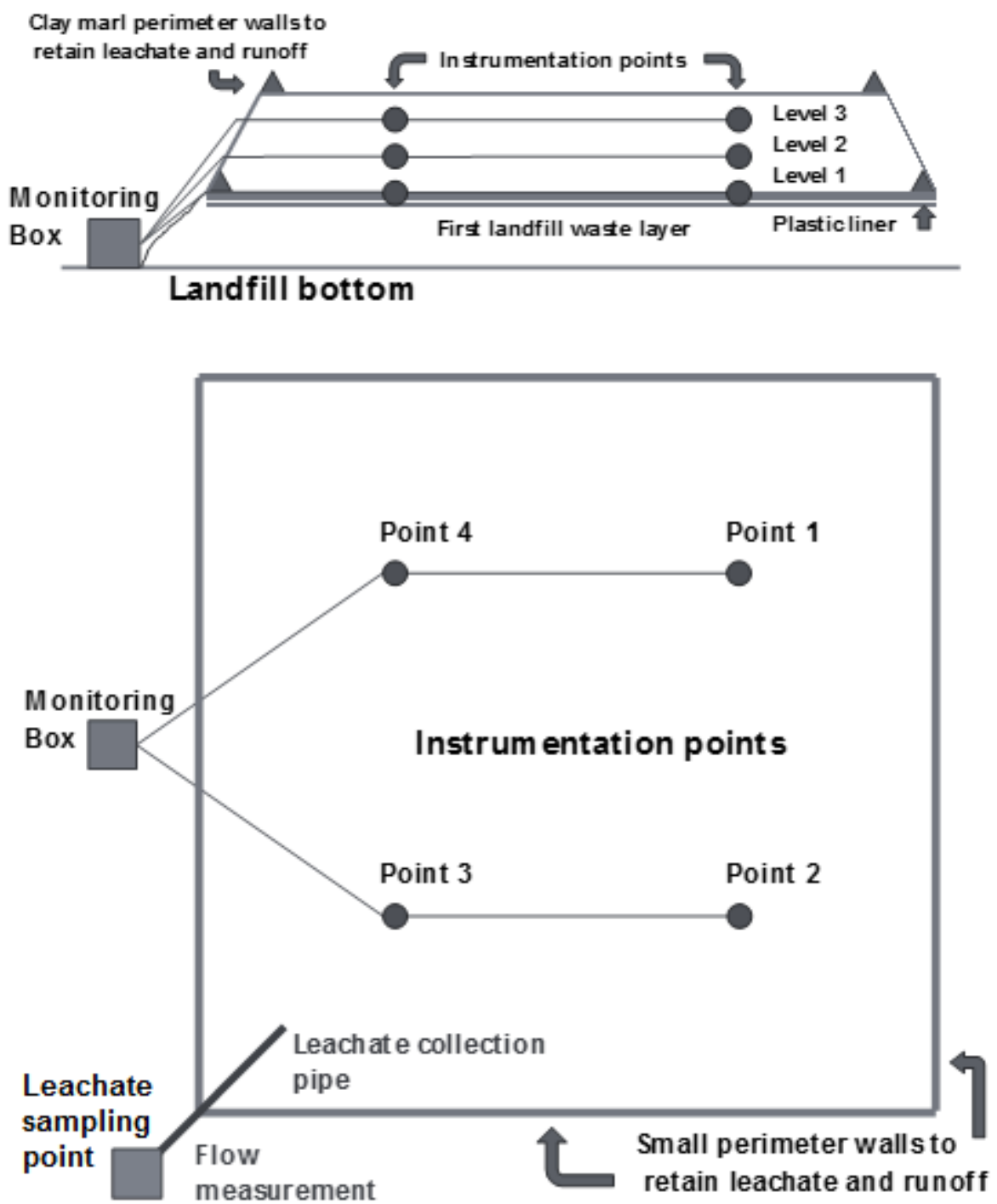

Figure 1. Scheme of the pilot-scale cell 


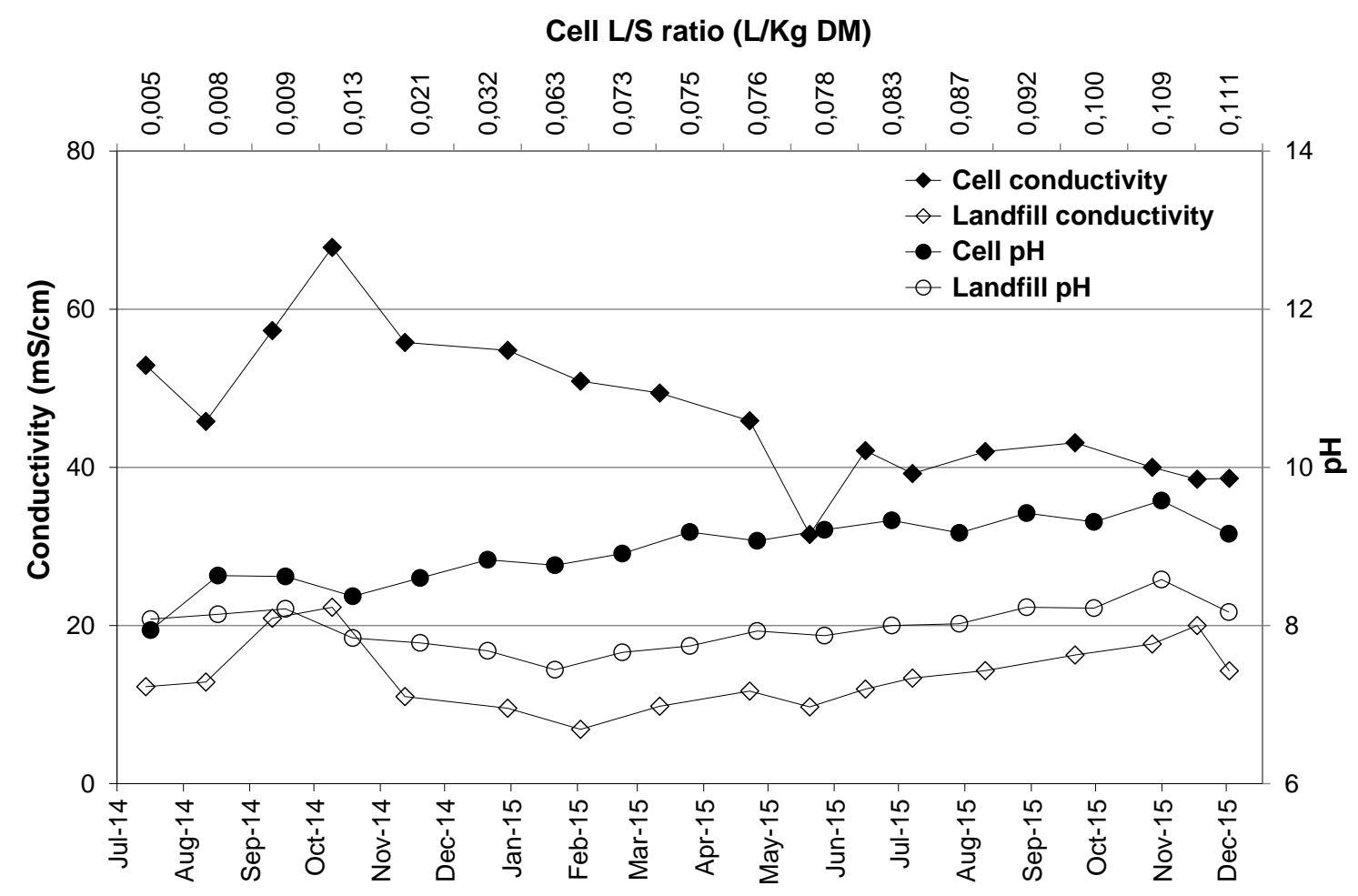

Figure 2. Evolution of conductivity and $\mathrm{pH}$ in the leachate with the L/S ratio 

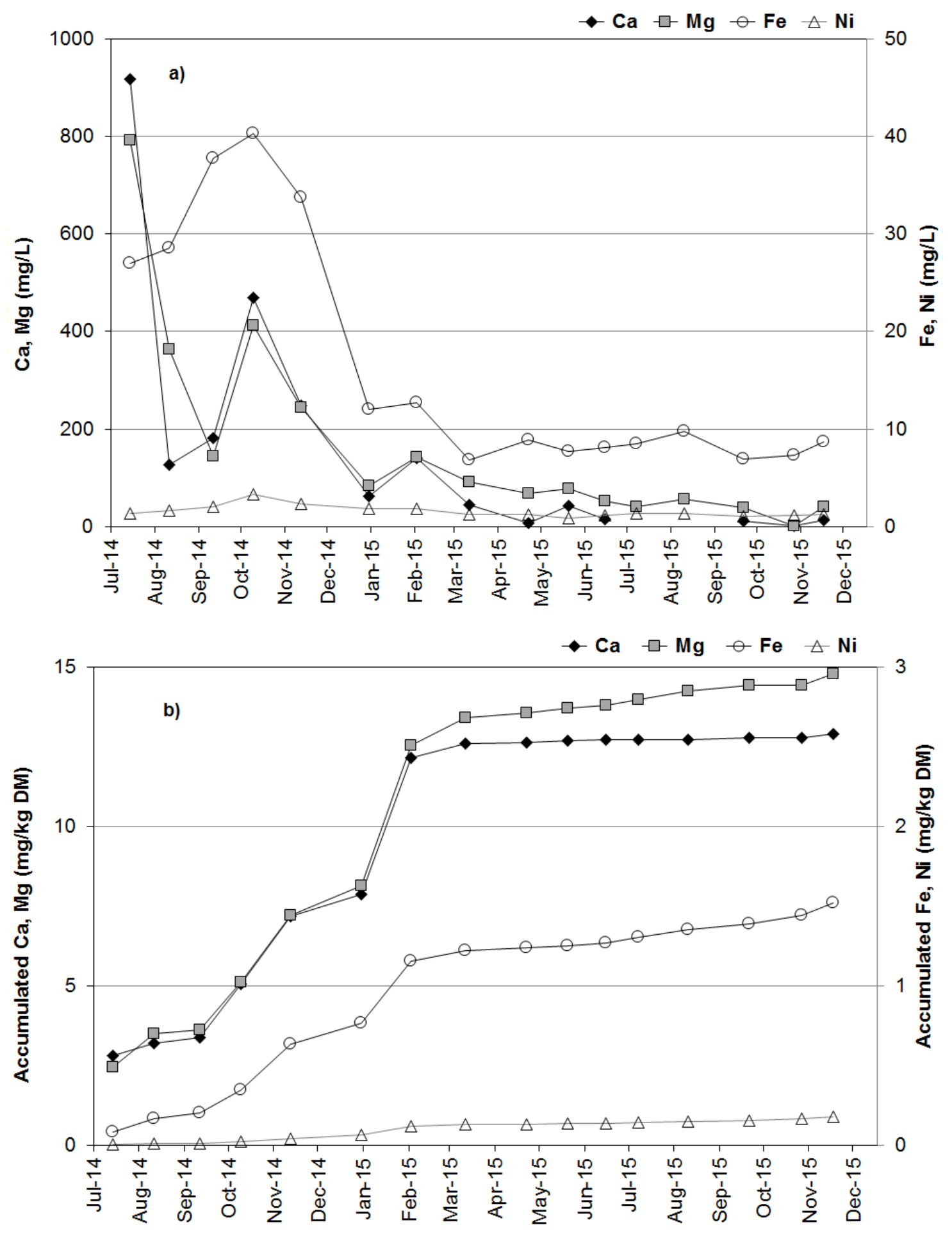

Figure 3. Evolution a) and accumulated liberation b) of $\mathrm{Ca}, \mathrm{Mg}$, $\mathrm{Fe}$ and $\mathrm{Ni}$ in the leachate 

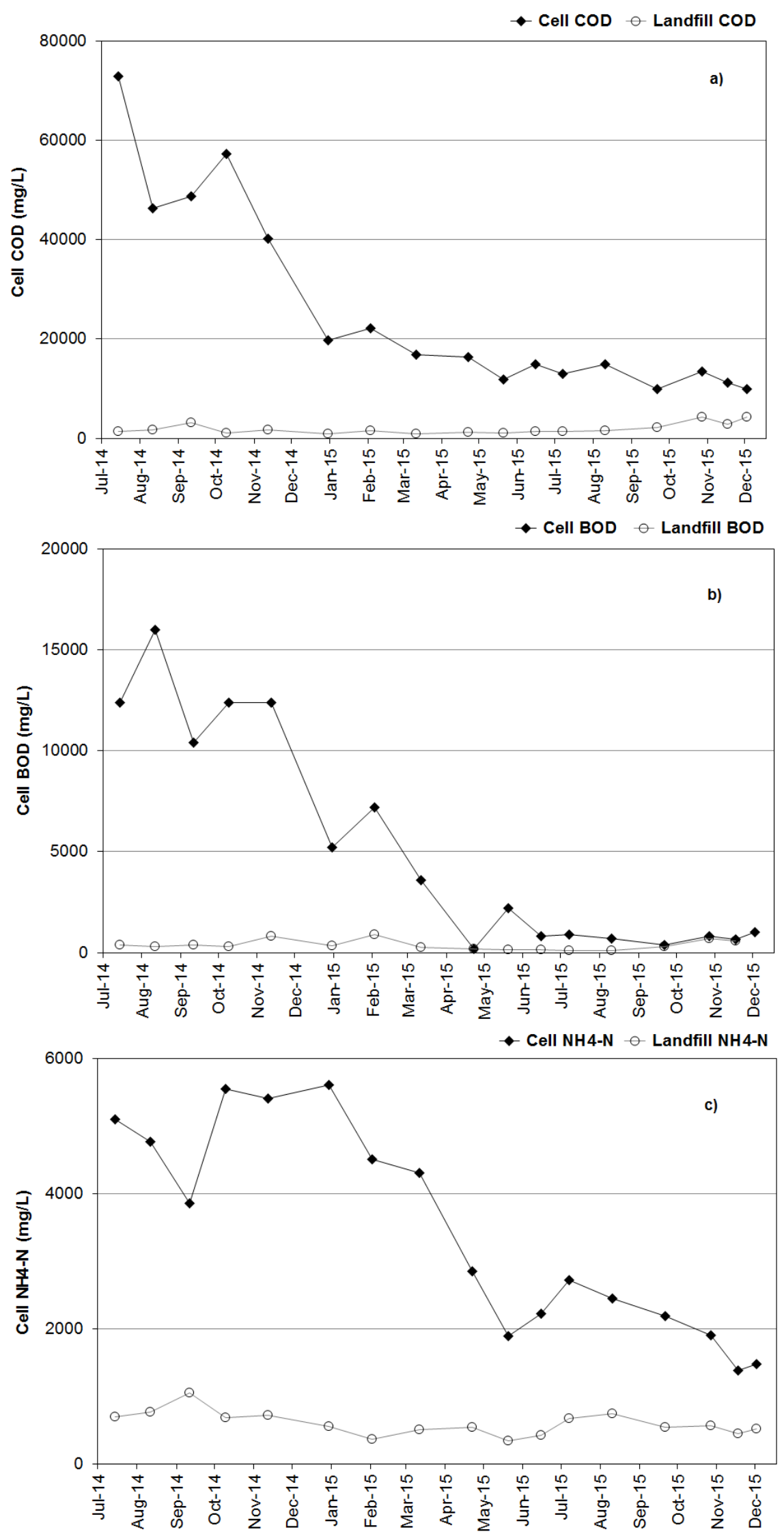

Figure 4. Evolution of a) $\mathrm{COD}, \mathrm{b}) \mathrm{BOD}$ and c) $\mathrm{NH}_{4}-\mathrm{N}$ in the leachate 


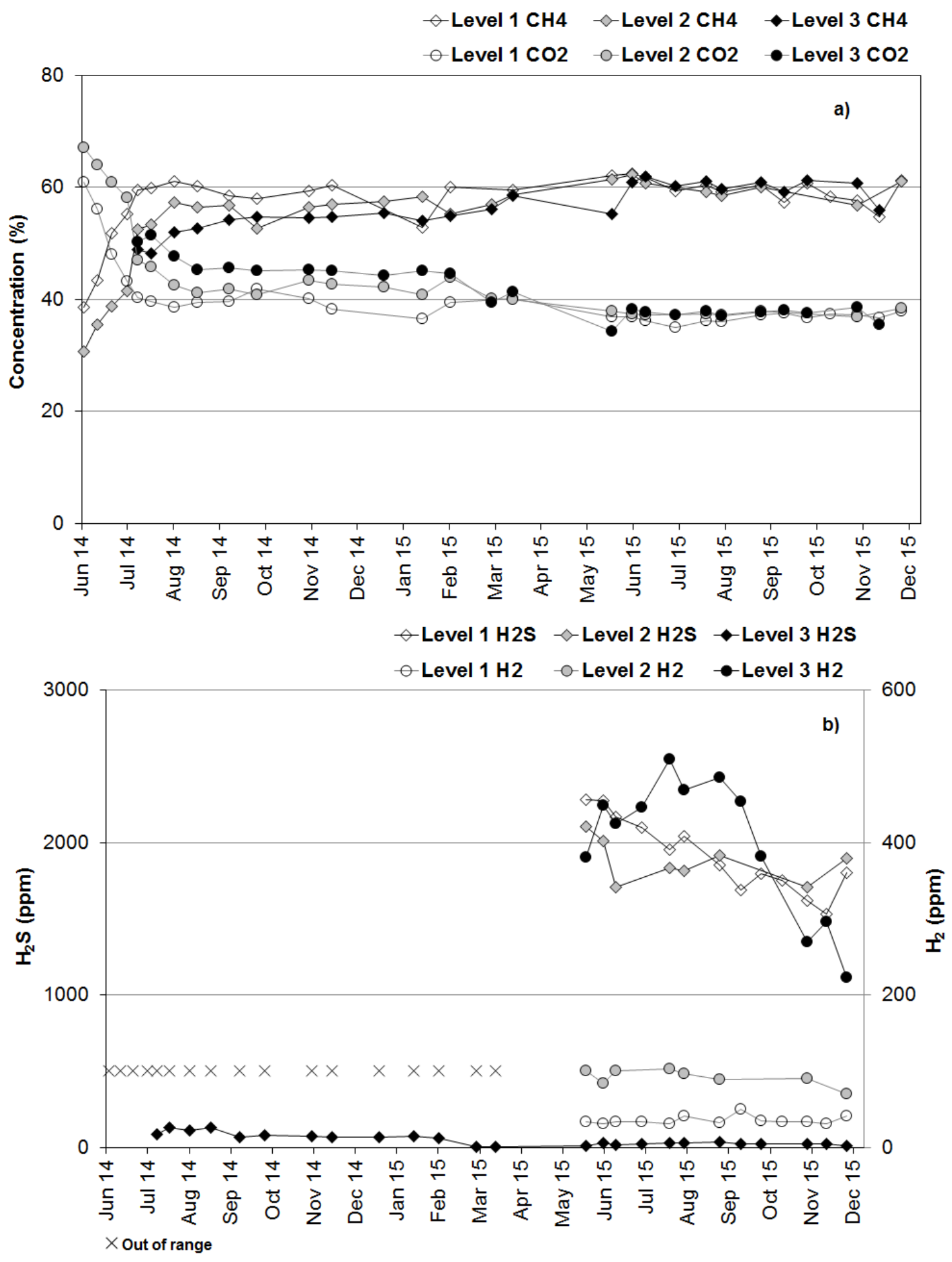

Figure 5. Evolution of the concentration of a) $\mathrm{CH}_{4}$ and $\mathrm{CO}_{2}$ and b) $\mathrm{H}_{2} \mathrm{~S}$ and $\mathrm{H}_{2}$ in the biogas within the cell 


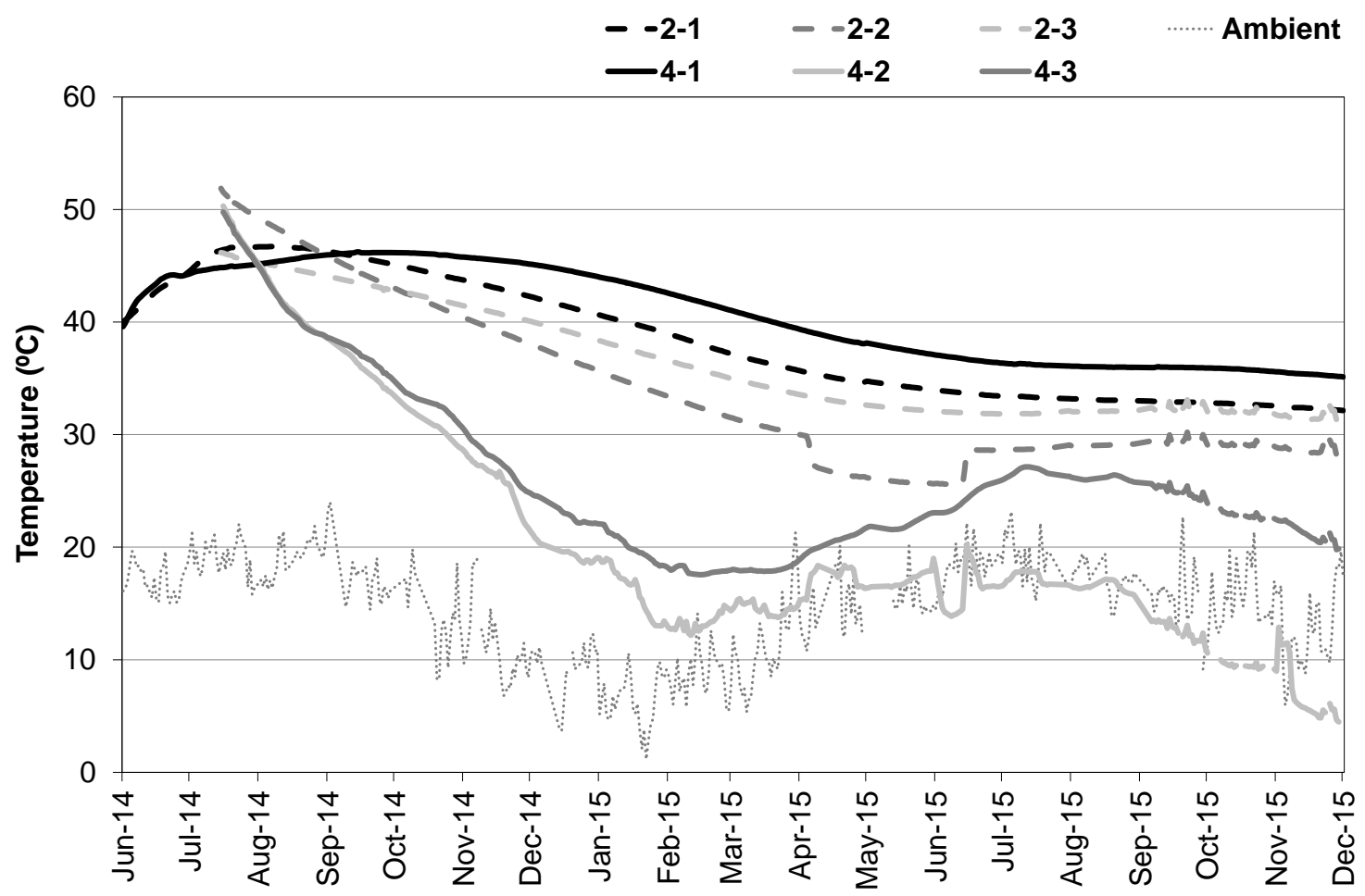

Figure 6. Evolution of the temperature inside the cell 